\title{
Relative contribution of public sector, banking sector, and non-bank financial sector claims in U.S. global banks' exposure to foreign counterparties' default risks
}

\author{
Ibrahim Niankara, Hassan Ismail ${ }^{a, b}$ \\ ${ }^{a}$ College of Business, Al Ain University of Science and Technology, P.O. Box: 112612, Abu Dhabi, UAE; Tel: \\ +97124444696 Ext: 539 ; Fax: +97124444304; E-mail: ibrahim.niankara@aau.ac.ae \\ ${ }^{b}$ Department of Accounting, Finance and Banking, Al Ain University of Science and Technology, P.O. Box: \\ 112612, Abu Dhabi, UAE; Tel: +97124444696 Ext: 595 ; Fax: +97124444304 ; E-mail: hassan.ismail@aau.ac.ae
}

\begin{abstract}
This paper relies on accounting-based measures of country risk to investigate U.S. global banks' exposure to foreign country risk over the 2017 fiscal year as measured by the sum of cross-border risk, foreign office risk, and derivative risk claims. We achieve this using panel linear modeling methods with country level heterogeneity and time fixed effects, along with a constructed panel data of 284 observations on 71 countries distributed across 6 world regional blocks, and observed over 4 consecutive quarters starting from 4th quarter 2016 and ending with 3rd quarter 2017.

The results show that on average, over the four quarters, a $1 \%$ increase in foreign banking sector's claims significantly increases U.S. global banks cross border risk exposure by $0.34 \%$, while reducing derivative risk exposure by $0.22 \%$, but have no significant impact on foreign office risk exposure. Similar results are observed with public sector claims which significantly increase banks' exposure to cross border risk by $0.21 \%$, while reducing derivative risk exposure by $0.19 \%$. Conversely however, non-bank financial sector claims are found to have no significant affect on cross-border risk exposure, but significantly reduce foreign office risk exposure by $0.09 \%$, while increasing derivative risk exposure by $0.06 \%$.

These results indicate the presence of sectoral heterogeneities in U.S. banks' exposure to foreign counterparties' risk, and also that overall, over the course of 2017 the level of U.S. global banks' crossborder risk exposure increased, while their level of derivative risk exposure decreased, and the level of foreign office risk exposure remained relatively unchanged.
\end{abstract}

Keywords: Bank Reporting, Country Risk, Financial Stability, Panel Data Modeling JEL: E51, F2, F34, G2, G32 


\section{Introduction}

Walter Bagehot, a renowned nineteenth-century economist, once stated that "the characteristic danger of great nations is that they may at last fail from not comprehending the great institutions they have created" (Houpt, 1999). In recent years banks have become so large and more complex, offering multiple services and products through operations spanning the globe, that it is sometimes challenging to identify on which side of banks' balance sheets vulnerabilities might emerge, or assess how vulnerabilities in one part of the financial system might affect other parts Auer et al., 2017; Baskaya et al., 2017; Bonfim et al., 2017; Caccavaio et al., 2017; Hills et al., 2017). The great financial crisis of 2008 revealed major shortcomings in focusing global banks' risk management efforts at the country level and neglecting sectors, thereby pointing out critical gaps in the available data for monitoring and responding to financial risks to economic stability Cetorelli and Goldberg, 2009; Sedunov, 2016). As a response, in 2012 the Committee on the Global Financial System (CGFS), the agency overseeing the Bank of International Settlement (BIS) approved a set of enhancements to the International banking Statistics (IBS) in order to fill the observed data gaps (Avdjiev et al., 2015). The two major enhancements made were the expansion of banks' balance sheets coverage to include their domestic positions and international activities; and also to provide more information about the sectors of banks' counterparties and banks' exposures (Kharroubi and Kohlscheen, 2017). This was done within mind that even when vulnerabilities are not quite apparent through a country's macro-economic indicators, weaknesses in particular sectors can still be transmitted globally through cross-border bank exposures and have wider consequences for financial stability (Grilli et al., 2014; Jang, 2017; Lee, 2017; Rose and Spiegel, 2010, 2011).

In the United States, the Federal Financial Institutions Examination Council (FFIEC) is the formal inter-agency body empowered to prescribe uniform principles, standards, and report forms for the federal examination of financial institutions by the Board of Governors of the Federal Reserve System (FRB), and to make recommendations to promote uniformity in the supervision 
of financial institutions. The FFIEC collects data similar to the BIS, through its FFIEC 009 and FFIEC 009a report: ${ }^{1}$, The reports provide quarterly data on non-U.S. exposures of United States banking institutions, where claims on an ultimate-risk basis for a given country exceed one percent of the U.S. banks' total assets or 20 percent of its total capital, whichever is less. A major purpose of collecting this data is to identify country risk, that is the potential for a claim on a foreign counterparty held by a U.S. bank to become impaired or eventually subject to losses (Palmer, 2000). Given the levels of market volatility observed in most countries during the financial crises (Aoki and Nikolov, 2015, Boissay et al., 2016; Gregory, 2010), attention to claims on foreign counterparties provides the opportunity to better shield the U.S. financial system against external shocks(Lee, 2017; Niepmann and Schmidt-Eisenlohr, 2017). IBS latest report on global banks' activities shows a growth in International banks' claims in the first quarter of 2017 Kharroubi and Kohlscheen, 2017). This growth led by a 2.8\% year-on-year growth of claims on the non-bank sector, turned positive for the first time since the first quarter of 2015. Total outstanding U.S. dollar credit (bank loans plus debt securities issuance) to the non-financial sector outside the United States rose from $\$ 8$ trillion at the end of September 2016 to $\$ 8.2$ trillion at the end of March 2017; or from $\$ 10.5$ trillion to $\$ 10.7$ trillion if non-bank financial borrowers are included. This observed large volume of cross-border loans by U.S. global banks' to foreign counterparties may significantly affect their risk exposure, with potential threat to the stability of the U.S. financial system at large(D'Avino, 2018; Liu and Pogach, 2017). Therefore the main objective of this paper is simply to update Palmer (2000) by examining U.S. global banks and asking the following question:

Does U.S. Banking institutions' ultimate sectoral claims on foreign counterparties significantly expose them to short term default risks between 4th quarter 2016 and 3rd quarter 2017 ?

\footnotetext{
${ }^{1}$ Statistical Releases - E.16 Country Exposure Lending Survey and Country Exposure Information Report, available at https://www.ffiec.gov/E16.htm
} 
Providing an answer to the above question allows U.S. banking organizations and banking system's supervisors to identify the sectors with significant contributions to U.S. financial market volatility. Foreign sectors identified as having elevated marginal contributions to foreign country risk can receive greater scrutiny to understand the nature and reasons of the elevated risk, but also the potential system wide consequences of those risks (Cetorelli and Goldberg, 2011). Doing so allows for the device of preventive measures for better risk management, and financial stability.

In general, the interaction of supply and demand of foreign capital in international financial markets determine foreign borrowing (Imbierowicz and Rauch, 2014, Rose and Spiegel, 2010), and thus banks' claims on foreign counterparties. Understanding supply and demand behavior in international financial markets is therefore important to understanding the factors that contribute to U.S. banks claims on foreign counterparties (Cetorelli and Goldberg, 2011).

To achieve this we assume that in the price/quantity plane, U.S. global banks determine a supply curve for each country which reflects banks' perception of the country's creditworthiness and reputation. The foreign country will also determine its demand curve in the same price/quantity plane, with the interaction of the two curves generating the equilibrium amount of foreign borrowing (and thus U.S. claims), and the interest rate.

Assuming that each borrowing country is a price taker in the international financial market, and also that U.S. global banks can supply as much funds as demanded by foreign counterparties at the prevailing market interest given a minimum level of creditworthiness and reputation (Claessens, 2006), then we can examine foreign counterparties' behavior in determining their demand for loanable funds, and the resulting foreign claims by U.S. banks (Bruno and Shin, 2014). As such, in what follows, we first describe in section 2 the sources of U.S. banks' claims on foreign counterparties, and foreign country risk. Next, in section 3 we describe the willingness to repay of foreign counterparties. In section 4 we discuss the empirical strategy including data, variables description, and econometric specification. In section 5 we present and discuss the results, while 
section 6 concludes the analysis.

\section{Foreign Country Risk and Sources of U.S. Banks Financial Claims}

The aim of this section is to provide a theoretical basis for U.S. banking institutions' financial claims on foreign counterparties, so as to understand the banks' vulnerability to different foreign sectors. Although several models have been used to describe default risk in the literature(Creal et al., 2014; Clerc et al., 2015; Koopman et al., 2012), In this paper we'll rely on the "development cycle hypothesis", and assume that U.S. banking institutions' claims are the result of prior financial resource demand (borrowing) by foreign counterparties (financial capital consumers) Mckinnon (2010). Excess demand for financial resources before U.S. banks leads to foreign debt accumulation and increase in U.S. banks' claims. We further assume that the demand for foreign debt before U.S. banks is divided into (i) government sector demand (leading to public sector claims), and (ii) private sector demand by banks and non-bank financial institutions (leading to "banking sector claims" and "non-bank financial sector claims"). Since most borrowing countries have relatively little domestic savings, and very limited domestic capital markets (Aretz and Pope, 2013), their public and private sectors may resort to international financial markets in order to meet national required investments, and shelter domestic consumption from income fluctuations (Herrero and Peria, 2007).

\subsection{Sources of Public Sector Claims}

Foreign government sector's demand for financial resources before U.S. global banks generates the public sector claims reported to the U.S. Federal Financial Institutions Examination Council (FFIEC), using the FFIEC 009 and FFIEC 009a reports. Following Theil (1965) optimal decision rule for government, we assume that a foreign government is able to accomplish its primary objective of remaining in office if it is able to achieve three major sub-objectives: (i) increase national income, (ii) increase domestic government spending, and (iii) improve the economy's 
business-friendly environment for foreign investment. The last objective can also be seen as embodied in the first two, such that the government is seen as faced with a quadratic preference function $\theta($.$) , and two sets of linearly related variables: X$ - the controlled variables affecting government preference levels (namely economic growth, and government expenditure), and $Y$ - the non-controlled variables (representing foreign financial resources from U.S. banks and others, and the country's exchange rate with the U.S. dollar).

The government's problem is therefore that of maximizing the quadratic preference function $\theta(X, Y)$ subject to a set of linear constraints linking controlled and non-controlled variables $Y=$ $R X+S$. Where $R$ is an $n \times m$ matrix of fixed elements describing the multiplicative structure of the constraints, and $S$ is an $n \times 1$ vector of stochastic variables. Assuming all regularity conditions, Theil (1965) shows that resolving the government's problem yields the following optimal condition:

$$
X^{0}=-K^{-1} k
$$

where $X^{0}$ is a maximum as long as

$$
\frac{\partial^{2} \theta}{\partial X^{2}}=K<0
$$

with $X^{0}$ representing the optimal levels of the control variables, $K$ an $n \times m$ symmetric matrix, and $k$ is an $n \times 1$ vector. We get the optimal levels of the non-controlled variables (such as the foreign financial resources from U.S. banks) $Y^{0}$ using the linear constraints $Y=R X+S$. These optimal governmental choices also generate U.S. banks' public sector claims on foreign countries.

\subsection{Sources of Private Sector (Banking sector and Non-Bank Financial Sector) Claims}

Foreign private sector demand for financial resources before U.S. banking institutions generate both, foreign banking sector claims and non-bank financial sector claims reported by banks in the FFIEC 009 and FFIEC 009a reports. Since foreign private sectors demand capital supplied by U.S. banks to finance investment projects (Herrmann and Mihaljek, 2013), we resort to the 
asset demand literature Mckinnon, 2010) to discuss private sector's financial resource demand and resulting U.S. banks claims (Bruno and Shin, 2014).

We assume that foreign banks and non-bank financial institutions plan activities for $\mathrm{n}$ periods in the future, depending on the state of technology and on input and output prices. At each point in time, they have three sources of returns: profits from output sales, and returns from two portfolios: financial and real assets (Elton and Gruber, 1997). In the foreign private sectors' optimal financial portfolio, borrowed U.S. financial resources represent one asset (with negative returns) among others. To determine their optimal financial portfolios, foreign banks and nonbank financial institutions maximize total returns subject to total wealth (Klein and Bawa, 1976). Assuming further that banks are homogeneous, and so are non-bank financial institutions, and also risk averse, then we can aggregate single foreign counterparty banks' demand to establish a foreign banking sector demand for U.S. borrowing, and similarly, aggregate single foreign counterparty non-banks' financial institutions demand to establish a foreign non-bank financial sector demand for U.S. borrowing(Herrero and Peria, 2007). These two types of demands therefore generate the banking sector claims, and non-bank financial sector claims reported by U.S. global banks in FFIEC 009 and FFIEC 009a reports.

\subsection{Inter-related Public, and Private (Banking and Non-Bank Financial Institutions) Sectors}

Although foreign public sector, banking sector, and non-bank financial sector have distinctive demand functions, they are in fact inter-related. This leads to inter-related sectoral claims by U.S. banking institutions. Indeed foreign private sector's demand, and supply of U.S. banks is strongly affected by foreign public sector's behavior and reputation in international capital markets. When foreign public sector is able to access the international financial capital market, international creditors including U.S. banks will be encouraged to deal with the foreign private sector, with or without public sector guarantee. Similarly, foreign banks and non-bank financial institutions are able to access sources of funds not normally open to public sector borrowing, giving the foreign 
country a cost advantage and a potential to increase its total borrowing if needed.

In addition, when foreign public sector acquire new contract before international creditors including U.S. global banks, the foreign private sector may view this new capital inflow as possible opportunities for private investment. For example when the funds are used to finance new public infrastructure projects, private sector banks and non-bank financial institutions may anticipate higher rate of economic growth, and in turn more private investment opportunities. Therefore all three sectors (public, banking, non-bank financial institutions) have to be combine in the estimation of a foreign country's demand for international financial resources. And in analyzing claims and overall foreign country risk, one needs to consider the dynamics between these 3 sectors.

Central to our understanding of credit relations between foreign countries and U.S. banking institutions is identifying the incentives for foreign counterparties to repay, and for U.S. global banks to continue supplying capital. To the extent that foreign counterparties can take actions to increase the likelihood of loan repayment, they will be better off, since doing so will increase U.S. banking institutions' willingness to lend. Similarly, to the extent that U.S. global banks can take actions to increase the likelihood that they will continue to renew their loans, foreign counterparties may be more willing to borrow and repay.

\section{Willingness to repay of Foreign Counterparties}

Following Eaton et al. (1991) exposition's in "the pure theory of country risk", we first focus on the behavior of foreign counterparties, and then we turn our attention to U.S. banking institutions. We do so with in mind that a foreign counterparty's willingness to pay depends on his beliefs about (i) U.S. creditor bank's resolve to penalize a recalcitrant counterparty, and (ii) U.S. creditor bank's willingness to lend in the future. 


\subsection{The general structure of the model with penalties}

This model assumes two-periods where the foreign counterparty contracts an amount of debt $D$ before a U.S. bank in the first period, with an obligation to repay $r(D)$ in the second period. The model ends after the second period, so that there are no further considerations that affect the participants. Let the event "the debt is repaid" be indexed by "1", and its complement event, "the debt is not repaid- default" be indexed by "0". If the foreign counterparty does not discharge this obligation, the U.S. creditor bank levies a penalty $\bar{P}$ expressed in the same unit as $r(D)$. Therefore the foreign counterparty's welfare is a function $U[D, x]$ which increases with the amount of debt, $D$, and decreases in the obligation imposed by the loan, $x$, with:

$$
x= \begin{cases}r(D) & \text { if repayment } \\ \bar{P} & \text { if default. }\end{cases}
$$

The foreign counterparty who defaults in the second period receives a total utility of:

$$
U_{0}=U[D, \bar{P}]
$$

while his utility in case of debt servicing as agreed is:

$$
U_{1}=U[D, r(D)]
$$

The counterparty then chooses to service the debt as long as:

$$
U_{1} \geq U_{0}
$$

This utility comparison is at the heart of the willingness-to-repay approach. Under the assumption that U.S. banks are competitive and face an opportunity cost of idled funds $i$, the amount of the repayment they require is:

$$
r(D)=(1+i) D
$$


Substituting equations $3,4,5$ and 7 into 6 implies that repayment occurs when:

$$
D \leq \frac{\bar{P}}{(1+i)}
$$

As long as U.S. creditor banks understand the foreign counterparty's situation, the following central conclusions can be stipulated:

- Foreign counterparties may be credit constrained. If the counterparty wishes to borrow a little more than $\bar{P} /(1+i)$ at rate $i$, he can't. Conversely, the counterparty needs not wish to borrow as much as he can.

- There is never any inconsistency between the state of nature, and a debt contract that says the counterparty must repaid with interest at rate $i$.

- There is never an incentive to impose penalties

- If the foreign counterparty wants to borrow more, he benefits from an increase in the penalty $\bar{P}$.

- If there is no penalty, one observes no lending by U.S. creditor banks rather than a series of debt contract violations.

The above conclusions of the general model with penalties, suggest that willingness-to-repay is a theory of rationing, rather than one of lender losses. However, it can be used as a mechanism to organize other formulations of the willingness-to-pay approach. For example one modification that changes the fourth conclusion on the welfare effects of increased penalties, while leaving the other conclusions unchanged, is the assumption of large debtor country. In fact, if the foreign counterparty is large, or if we consider simultaneous increases in the penalties applied to a large number of counterparties, then increasing $\bar{P}$ may raise the world interest rate to the counterparty's disadvantage. In the extreme, if the financial resources available to U.S. creditor banks are fixed, an increase in $\bar{P}$ raises $i$ without affecting $D$. 


\subsection{The general structure of the model under Uncertainty}

In this extension of the initial model, we introduce risk and assume that the penalty in case of default depends on the state of nature, $s$, such that

$$
P=P(s)
$$

The utility of a foreign defaulting counterparty is:

$$
U_{0}=U[D, P, s]
$$

while this utility in case the loan is serviced as agreed is:

$$
U_{1}=U[D, r(D), s]
$$

With the argument $s$ indicating that utility may depend on the state of nature in other ways than just through the default penalty $P$. The amount of the payment $r(D)$, does not depend however on the state of nature. The counterparty chooses to service the loan in all states $s$ in the state space $S$ as long as:

$$
U_{1} \geq U_{0}
$$

otherwise, that is for all $s$ in the complement space $S^{\prime}$ the counterparty will choose to default. The foreign counterparty's expected utility is therefore given by:

$$
\int_{S} U_{1} f(s) d s+\int_{S^{\prime}} U_{0} f(s) d s,
$$

Where $f(s)$ is the probability of state $s$. If U.S. creditors banks are competitive and face an opportunity cost of idled funds $i$, the amount of the repayment they require is:

$$
\pi r(D)=(1+i) D
$$

with probability of repayment given as:

$$
\pi=\int_{S} f(s) d(s)
$$


In this formulation, the presence of uncertainty implies that foreign counterparties may default on their loan agreement, and that U.S. banks may also impose penalties. An increase in the penalty need not increase the foreign counterparty's expected utility. Although such increase will tend to raise the amount lent to the counterparty's benefit; in those states where the foreign country defaults, it may be worse off doing so.

Conversely however, uncertainty need not imply that the probability of repayment $\pi<1$, if the repayment schedule can also be made contingent on the state of nature, s. In which case, the state contingent repayment, $r(D, s)$, is chosen so that $U_{1} \geq U_{0} \forall s$. In this formulation, U.S. creditor banks cannot revise the contractual interest rate upward, unless the foreign counterparty violates the contract. The contractually specified payment must therefore be the maximum of the payments in all possible states, $r^{+}(D)=\max _{s} r(D, s)$. In the terminology of Grossman and Van Huyck (1988), a default could be considered excusable for any state $s$ with $r(D, s)<r^{+}$, such that penalties are only levied in case the foreign counterparty pays less than $r(D, s)$, not less than $r^{+}$.

\section{Empirical Strategy}

This section first presents the sources of the data used in the empirical analysis, then describes next the different risk ratios constructed as accounting-based measures of risk, and used as dependent variables. This is followed by a description of the three constructed independent variables characterizing the sectoral risk claims. Finally the last part of this section describes the econometric specification and model identification strategy.

\subsection{Data}

The empirical analysis is based on Data from the 2017 Country Exposure Lending Survey (CELS), collected by the U.S. Federal Financial Institutions Examination Council (FFIEC) using two reports, the FFIEC 009 and the FFIEC 009a. The CELS provides quarterly data on non-U.S. 
exposures of United States banking institutions, where claims on an ultimate-risk basis for a given country exceed one percent of the U.S. banks' total assets or 20 percent of its total capital, whichever is less. The FFIEC 009 report collects detailed information on the distribution, by country, of claims on foreigners held by certain U.S. banks, savings associations, bank holding companies, savings and loan holding companies, and intermediate holding companies. While the FFIEC 009a is a supplement to the FFIEC 009 and provides specific information about the reporting institutions' exposures in particular countries ${ }^{2}$.

The report was initiated in 1977 as the FR 2036 report and was used to collect data on the distribution, by country, of claims on foreigners held by U.S. banks and bank holding companies. The Federal Deposit Insurance Corporation (FDIC) ${ }^{3}$ and the Office of the Comptroller of the Currency $(\mathrm{OCC})^{4}$ collected similar information from institutions under their supervision. In March 1984, the FR 2036 became a Federal Financial Institutions Examination Council (FFIEC) report and was renumbered FFIEC 009. It was revised in March 1986 to provide more detail on guaranteed claims. In 1995, the report was revised to add an item for revaluation gains on off-balance-sheet items and an item for securities held in trading accounts, and several items were combined.

All data collected through the FFIEC 009 report are fully consolidated following U.S. generally accepted accounting principles (GAAP) and cover 68 U.S. banking organizations (including U.S.

\footnotetext{
${ }^{2}$ Total cross-border exposures reported on the FFIEC 009a align with the cross-border disclosures reported in the U.S. Security and Exchange Commissions (SEC) Form 10-K. However, cross-border exposures differ from country risk exposures and the differences are outlined in U.S. banking institutions SEC Form 10-K.

${ }^{3}$ represents an independent agency created by the U.S. congress to maintain stability and public confidence in the nation's financial system by insuring deposits, examining and supervising financial institutions for safety and soundness and consumer protection. See official page at https://www.fdic.gov

${ }^{4}$ an Independent bureau of the U.S. Department of the Treasury with the mission to ensure that national banks and federal savings associations operate in a safe and sound manner, provide fair access to financial services, treat customers fairly, and comply with applicable laws and regulations. See official page at https://www.occ.treas.gov
} 
holding companies owned by foreign banks, but excludes U.S. branches of foreign banks). All positions are reported on a gross basis, as of the last day of the quarter and in U.S. dollars regardless of the currencies in which the balances are denominated ${ }^{5}$,

In order to describe U.S. banking organizations' sensitivity to global risk exposure, we compile the claims data into a panel of quarterly data on 71 countries observed over four quarters starting from the last quarter of 2016, and ending with the 3rd quarter of 2017. We then derive accountingbased measures of foreign risk, using cross-border risk claims, foreign-office risk claims, and claims from derivative products on an ultimate-risks basi:6. For a given country, country risk claims measure the exposure of reporting U.S. banks to an event that might severely limit the ability of borrowers in that country to repay their debt.

\subsection{Dependent variables}

Since country risk claims are the sum of cross-border claims, foreign-office claims and claims on derivative products, we construct the following three accounting-based measures of risk ratios to represent our dependent variables:

1. Cross-border risk ratio (CrxBordRR), defined as $\frac{\text { Cross Border Claims }}{\text { Total Country Risk Claims }} * 100$

2. Foreign Office risk ratio (ForeignOfficRR) defined as $\frac{\text { Foreign Office Claims }}{\text { Total Country Risk Claims }} * 100$

3. Derivative risk ratio (DerivativRR) defined as $\frac{\text { Derivative Products Claims }}{\text { Total Country Risk Claims }} * 100$

\footnotetext{
${ }^{5}$ with the following exception: (i) Trading assets and trading liabilities in the same exact security may be reported on a net basis, also referred to as "CUSIP netting." (ii) Positive fair values of derivative contracts may be offset against negative fair values if, and only if, the transactions were executed with the same counter-party under a legally enforceable master netting agreement.

${ }^{6}$ that is, by country of guarantor after applying adjustments for guarantees or eligible collateral. Eligible collateral is collateral that is (a) liquid and readily-realizable, and (b) realizable outside of the country of residence of the borrower. Eligible collateral includes cash and investment grade debt or marketable equity securities
} 


\subsection{Independent variables}

As discussed in the theory section above, foreign risk claims are the result of foreign public sector demand, foreign banking sector demand and foreign non-bank financial sector demand of capital before U.S. global banks. Therefore we construct our main explanatory (independent) variables as:

1. Ratio of Public Sector Claims $(\mathrm{PbSctRR})=\frac{\text { Total ultimate claims on public sector }}{\text { Total Country Risk Claims }} * 100$

2. Ratio of Banking Sector Claims $(B k S c t R R)=\frac{\text { Total ultimate claims on banking sector }}{\text { Total Country Risk Claims }} 100$

3. Ratio of non-bank financial sector claims (NBkFinSctRR) which is defined as $=\frac{\text { Total ultimate claims on non-bank financial sector }}{\text { Total Country Risk Claims }} * 100$

\subsection{Econometric Specification}

Given the nature of the data, we rely on panel linear modeling methods, and define for all $i=$ $1, \ldots, 71 ; t=0,1,2,3 ;$ and $j=1,2,3$

$$
y_{i t j}=\beta_{2 j} P b S c t R R_{i t}+\beta_{1 j} B k S c t R R_{i t}+\beta_{3 j} N B k F i n S c t R R_{i t}+\alpha_{1 j} t_{1}+\alpha_{2 j} t_{2}+\alpha_{3 j} t_{3}+\epsilon_{i t j}
$$

where:

- $y_{i t j}$ is the observed risk ratio type $j$ in quarter $t$ for country $i$,

- $P b S c t R R_{i t}$ is the public sector financial risk ratio in quarter $t$ for country $i$,

- $B k S c t R R_{i t}$ is the banking sector risk ratio in quarter $t$ for country $i$,

- $N$ BkFinSctRR $R_{i t}$ is the non-banking sector financial risk ratio in quarter $t$ for country $i$,

- $\alpha_{t j}$ for $t=1,2,3$ represent the time dummy variables for the first 3 quarters of 2017 ,

- $\epsilon_{i t j}$ is the idiosyncratic term in the observed risk ratio $j$ in quarter $t$ for country $i$ 
we use two identification strategies to uncover the values of the coefficients in the linear model 16 . The first one is based on the pooled OLS estimator which assumes no significant cross sectional nor temporal effects, and the second estimation strategy is based on the panel fixed effects estimator. Both estimators are implemented using the "plm" function(Croissant et al., 2008) in the R statistical package (R Core Team, 2017).

\section{Results and Discussion}

This section presents both, the descriptive and econometric results. We first start with pair-wise Pearson's correlation tests of interrelated sectors and risks, then we move to discuss U.S. banks regional and quarterly risk exposures by foreign sector. Followed by a discussion of aggregate regional and aggregate quarterly heterogeneities in U.S. banks' risk exposure. Then, we discuss the poolability test to decide between the pooled ordinary least squares (OLS) estimator and the panel fixed effects estimator. Finally, we proceed to present the results of the model chosen by the poolability test as the most adequate for our data.

\subsection{Descriptive statistics}

The descriptive results are shown in table(1) and suggest minor quarterly variations in U.S. global banks' mean exposure to foreign counterparty risk between 4th quarter 2016 and 3rd quarter 2017. In fact, the highest overall mean is recorded for cross border risk at $62.70 \%$ with quarterly fluctuations between [61.53\%; 63.38\%], followed by foreign office risk, at an overall mean value of $32.59 \%$ with quarterly fluctuations between $[32.29 \% ; 33.08 \%]$. Derivative risk presents the lowest overall mean value at $4.71 \%$ with quarterly fluctuations between [4.33\%; 5.39\%].

Considering U.S. banks' claims variations by sector, we note that foreign banking sector has the highest mean ratio at 34.18\% with quarterly fluctuations between [33.16\%; 34.89\%], followed by public sector at an overall mean ratio of $22.25 \%$ with quarterly fluctuations between [21.56\%; 
$23.01 \%$ ], while the lowest overall mean ratio is recorded by the non-bank financial sector at $13.23 \%$ with quarterly fluctuations between [12.75\%, 13.03\%].

\subsection{Pearson's correlation test of Inter-related sectors and risks}

Recall from our theoretical discussion on the sources of U.S. global banks' risk claims on foreign counterparties, that because of interrelated demands from foreign public sector, banking sector and non-bank financial sector, we'll also have interrelated sectoral claims. We now proceed to test these interrelationships using Pearson's correlation test. This test is a parametric measure of the linear association between two numeric variables, and is implemented here through the function "cor.test" in the R statistical package (R Core Team, 2017). The numerical results are presented in table (2), while the graphical correlation test results are shown in figure (1). Together with the $95 \%$ confidence intervals, these results suggest that U.S. banking institutions' risk claims on foreign countries' public sector, banking sector, and non-bank financial sector are all significantly inter-related. In fact, not only are all confidence intervals void of zero, suggesting their significance, but also the p-values on the individual point estimates of the correlation coefficients are all less than the alpha significance level of 0.05 , therefore we could safely reject the null of no significant correlations.

\subsection{Aggregate regional heterogeneity in U.S. global banks' risk exposure}

Foreign countries with U.S. global banks counterparties are grouped into six world regions in the 2017 U.S. Country Exposure Lending Survey (CELS), therefore we use this fact to investigate regional level exposure of U.S. global banks to foreign risk. These six world regions are respectively : 1 - G10 countries plus Luxembourg (G10Lux), 2 - Non G10 developed countries (NG10DevC), 3 - Eastern European countries (EastrnEurop), 4 - Latin America (LatinAmer), 5 - Asia Pacific (AsiaPacif), and 6 - Africa. U.S. global banks' exposures to foreign counterparty risks (cross border risk, foreign office risk, and derivatives risk) from the above six world regions are decomposed 
by sector (foreign public sector, foreign banking sector, and foreign non-bank financial sector). Aggregate regional heterogeneities in U.S. global banks' exposure to risk are presented in figures (2), (3), and (4) respectively for cross border risk, foreign office risk, and derivative risk.

Focusing on cross border risk exposure, the results in figure (2) show major regional heterogeneities. In fact, we note that U.S. global banks' lowest risk exposure comes from counterparties in the Eastern European region at $47 \%$ (with 32 observations), followed by those in the Asia Pacific region at $53 \%$ (with 56 observations), then the African region at $55 \%$ (with 32 observations). Conversely, the highest exposure to banks' cross border risk comes from counterparties in the non-G10 developed countries at 79\% (with 56 observations), followed by those in the Latin American region at $68 \%$ (with 64 observations), and finally by those in the G-10 and Luxembourg at $63 \%$ (with 44 observations).

Moving on to foreign office risk exposure, the results shown in figure (3) also suggest major regional heterogeneities. The lowest foreign counterparty contributors to U.S. global banks' exposure to foreign office risk come from the non G-10 developing countries at 16\% (with 56 observations), followed by those from the G-10 and Luxembourg at 24\% (with 44 observations), then from those in Latin America at 29\% ( with 64 observations). Conversely, the highest contributors to banks' exposure to foreign office risk come from the Eastern Europe region at 51\% (with 32 observations), followed by those in the Asia Pacific region at 42\%(with 56 observations), and finally counterparties in the African region at $41 \%$ (with 32 observations).

Finally turning our attention to derivative risk exposure, the results in figure (4) suggest major regional heterogeneities as well. In fact, it can be noted that banks' lowest derivative risk exposure come from counterparties in the Eastern European region at below 2\% (with 32 observations), followed by those in the African region at slightly above $2 \%$ (with 32 observations), then from those in the Asia Pacific region at below 4\% (with 56 observations). The highest counterparty contributors to derivative risk come from the G-10 and Luxembourg at nearly $10 \%$ 
(with 44 observations) followed by those from non G-10 developed countries at around 7\% (with 56 observations), and finally from Latin American countries at below 4\% (with 64 observations).

\subsection{Aggregate quarterly heterogeneity in U.S. global banks' risk exposure}

Aggregate quarterly heterogeneities in U.S. global banks' exposure to risk are presented in figures (5), (6), and (7) respectively for cross border risk, foreign office risk, and derivative risk.

Focusing on cross border risk exposure, the results in figure (5) show minor quarterly heterogeneities. In fact starting from 4th quarter 2016 at an average of about $61.5 \%$ (with 71 countries), cross border risk level increases to about $63 \%$ in the 1st quarter 2017, then decreases slightly to about $62 \%$ in 2 nd quarter 2017, then increases back slightly again to about $62.5 \%$. Overall, over the course of 2017, U.S. global banks' cross border risk exposure increased by 1 percentage point, from $61.5 \%$ to $62.5 \%$.

Moving on to foreign office risk exposure, the results shown in figure (6) also suggest minor quarterly heterogeneities. Begining 4th quarter 2016 at an average foreign office risk of 33\% (with 71 countries), this figure decreases to $32.5 \%$ in the first quarter 2017, then increases to $32.75 \%$ in the 2nd quarter 2017, and decreases back to 32.5\% in the 3rd quarter of 2017. These fluctuations suggest that overall, over the course of 2017, U.S. global banks foreign office risk decreased by less than 1percentage point at about $0.5 \%$.

Finally turning our attention to derivative risk exposure, the results in figure (7) suggest relatively more quarterly heterogeneities than the previous two cases. starting 4th quarter 2016 at an average derivative risk level of about $5.5 \%$ (with 71 countries), we observe a one percentage point decrease to $4.5 \%$ in the 1 st quarter 2017 , followed by a slight increase to $4.75 \%$ in 2 nd quarter 2017 , and ending with a decrease to $4.25 \%$ in the 3 rd quarter of 2017 . These results indicate that overall, over the course of 2017, U.S. banks' derivative risk exposure decreased by 1.25 percentage point from $5.5 \%$ to $4.25 \%$. 


\subsection{Poolability Tests}

The poolability test is performed to compare the performance of the pooled OLS regression model with the within fixed effect regression model, so as to decide which model is best suited. The question that this test attempts to answer is: Can we assume that there is neither significant cross sectional nor significant quarterly effects, and pool the data and run OLS regression model with constant intercept, and slope coefficients for banking sector risk ratio (BkSctRR), public sector risk ratio (PbSctRR), and non-bank financial sector risk ratio (NBkFinSctRR), across countries and quarters?

Compared to the fixed effect model, the pooled regression model is a restricted model, that imposes a common intercept on all countries across quarters such that: $\alpha_{0 j}=\alpha_{1 j}=\alpha_{2 j}=\alpha_{3 j}$ for all $j=1,2,3$. Therefore we implement a restricted $\mathrm{F}$ test given by:

$$
F=\frac{\left(R_{U R}^{2}-R_{R}^{2}\right) / J}{\left(1-R_{U R}^{2}\right) /(n-k)}
$$

where

- $R_{U R}^{2}=R^{2}$ of the unrestricted, fixed effect regression model

- $R_{R}^{2}=R^{2}$ of the restricted, pooled regression model

- $J=$ the number of linear restrictions on the pooled model

- $k=$ the number of parameters in the unrestricted regression

- $n=N T=$ the total number of observations

We implement the above described test in the $\mathrm{R}$ statistical package ( $\mathrm{R}$ Core Team, 2017) using the "PFtest" function in the library "plm" (Croissant et al. 2008). The results are summarized in the last rows of tables (3), (4), and (5) and suggest for all three risk measures that the panel fixed effect model is better. In fact, in the case of cross border risk, the poolability F-statistics is 
equal to 93.29 with corresponding $p$-value $<0.05$, therefore we reject the null of no individual country fixed effect, and hence conclude the evidence is enough to suggest that the panel fixed effect estimator is better. The same conclusions are drawn in the case of foreign office risk, and derivative risk which have respectively F-statistics values of 104.74 and 23.72, with corresponding $p-$ values $<0.05$.

Together, the three poolability test results suggest that we cannot assume there is neither significant cross sectional nor significant quarterly effects, and pool the data and run OLS regression model with constant intercept, and slope coefficients across countries and quarters, for banking sector risk ratio (BkSctRR), public sector risk ratio (PbSctRR), and non-bank financial sector risk ratio (NBkFinSctRR).

\subsection{Panel Fixed effects Model Results}

The results of the panel linear model with country level heterogeneity and time fixed effects are presented in the second columns of tables (3), (4), and (5) respectively for cross border risk, foreign office risk, and derivative risk.

Starting with the results of the cross border risk model, column two of table (3) shows that although non-bank financial sector claims do not seem to significantly contribute to cross border risk, banking sector and public sector claims do. In fact, the results suggest for every $1 \%$ increase in banking sector claims during 4th quarter 2016 to 3rd quarter 2017, U.S. global banks' cross border risk exposure increases by $0.34 \%$. Similarly, with every $1 \%$ increase in public sector claims, cross border risk exposure increases by $0.21 \%$. Furthermore, the results of the estimated time fixed effects suggest for the case of cross-border risk exposure, that compared to its average level in the 4th quarter of 2016, the average cross-border risks exposure in the 1st and 3rd quarters of 2017 are respectively $1.83 \%$ and $2.00 \%$ significantly higher.

Moving to the results of the foreign office risk model, column two of table (4) shows that among all the foreign sectors, only the non-bank financial sector seems to significantly affect U.S. banks' 
foreign office risk exposure. More specifically, we note that every $1 \%$ increase in foreign non-bank financial sector claims reduces U.S. global banks foreign office risk by $0.09 \%$. This result therefore indicates a significant trade-off between U.S. global banks' non-bank financial services activities and their foreign office expansion activities during 4th quarter 2016 to 3rd quarter 2017.

Now turning to the results of the derivative risk model, column two of table (5) shows that all three sectors significantly affect U.S. banks derivative risk. In fact we note that every $1 \%$ increase in both banking sector claims and public sector claims reduce U.S. banks exposure to foreign derivative risk by $0.22 \%$ and $0.19 \%$ respectively. Furthermore, the results of the estimated time fixed effects suggest for the case of derivative risk exposure that its average level in the 1st and 3rd quarters of 2017 are respectively $0.82 \%$ and $1.00 \%$ lower than the initial derivative risk exposure in 4 th quarter 2016.

\section{Conclusions}

The aim of this paper was to use the latest data on U.S. global banks' claims on foreign counterparties, to not only assess banks' exposure to foreign country risk as measured by the sum of cross border risk, foreign office risk, and foreign derivative risk; but also to get a clear picture of the various foreign sectors with significant treat to U.S. banks' stability. To achieve this goal, we used quarterly collected data from the 2017 U.S. country exposure survey, collected by the Federal Financial Institutions Examination Council (FFIEC) using two reports, the FFIEC 009 and the FFIEC 009a. This data was then used to investigate global banks' vulnerabilities to counterparties' from foreign public sector, banking sector, and non-bank financial sector through a series of graphical and numerical risk analysis.

The results showed that on average, over the four quarters beginning 4th quarter 2016 to 3rd quarter 2017, a 1\% increase in foreign banking sector claims significantly increased U.S. global banks cross border risk exposure by $0.34 \%$, while reducing their derivative risk exposure by $0.22 \%$, 
but had no significant impact on foreign office risk exposure. Similar results were observed with public sector claims which significantly increased U.S. global banks exposure to cross border risk by $0.21 \%$, while reducing derivative risk exposure by $0.19 \%$. Conversely however, non-bank financial sector claims were found to have no significant affect on cross-border risk exposure, but significantly reduced foreign office risk exposure by $0.09 \%$, while increasing derivative risk exposure by $0.06 \%$.

Furthermore, the results of the estimated time fixed effects revealed for the case of U.S. banks' cross-border risk exposure, that compared to its average level in the 4th quarter of 2016, the average levels of cross-border risk exposure in the 1st and 3rd quarters of 2017 were respectively $1.83 \%$ and $2.00 \%$ significantly higher. A similar result was observed with banks' derivative risk exposure, although in this case the average level in the 1st and 3rd quarters of 2017 were respectively $0.82 . \%$ and $1.00 \%$ lower than the initial derivative risk exposure in 4th quarter 2016. No significant time fixed effects were observed however in the case of banks' foreign office risk exposure. Together these results seemed to suggest that the three foreign sectors impact differently U.S. banks exposure to foreign country risk, and most importantly that, over the course of 2017, the level of U.S. global banks' cross-border risk exposure increased (most likely due to increased trade of non derivative assets), while their level of derivative risk exposure decreased (due to a reduction in the trade of derivative assets), and the level of foreign office risk exposure remained relatively unchanged.

Since the current analysis only considered accounting-based measures of country risk, future possible directions include extending the accounting based model to include other risk measures such as economic risk, political risk, as well as social development in order to get a much broader picture of U.S. global banks' exposure to foreign country risks. 


\section{References}

Aoki, K., Nikolov, K., 2015. Bubbles, banks and financial stability. Journal of Monetary Economics $74,33-51$.

Aretz, K., Pope, P. F., 2013. Common factors in default risk across countries and industries. European Financial Management 19 (1), 108-152.

Auer, S., Ganarin, M., Towbin, P., et al., 2017. International banking and cross-border effects of regulation: Lessons from switzerland. International Journal of Central Banking 13 (2), 65-93.

Avdjiev, S., McGuire, P., Wooldridge, P., 2015. Enhanced data to analyse international banking. BIS Quarterly Review.

Baskaya, Y. S., Binici, M., Kenç, T., et al., 2017. International banking and cross-border effects of regulation: Lessons from turkey. International Journal of Central Banking 13 (2), 379-403.

Boissay, F., Collard, F., Smets, F., 2016. Booms and banking crises. Journal of Political Economy 124 (2), 489-538.

Bonfim, D., Costa, S., et al., 2017. International banking and cross-border effects of regulation: Lessons from portugal. International Journal of Central Banking 13 (2), 341-377.

Bruno, V., Shin, H. S., 2014. Cross-border banking and global liquidity. The Review of Economic Studies $82(2), 535-564$.

Caccavaio, M., Carpinelli, L., Marinelli, G., et al., 2017. International banking and cross-border effects of regulation: Lessons from italy. International Journal of Central Banking 13 (2), 223247. 
Cetorelli, N., Goldberg, L., 2009. Globalized banks: lending to emerging markets in the crisis. Staff Report, Federal Reserve Bank of New York, No. 377.

Cetorelli, N., Goldberg, L. S., 2011. Global banks and international shock transmission: Evidence from the crisis. IMF Economic Review 59 (1), 41-76.

Claessens, S., 2006. Competitive implications of cross-border banking. In: Cross-Border Banking: Regulatory Challenges. World Scientific, pp. 151-181.

Clerc, L., Derviz, A., Mendicino, C., Moyen, S., Nikolov, K., Stracca, L., Suarez, J., Vardoulakish, A. P., 2015. Capital regulation in a macroeconomic model with three layers of default. International Journal of Central Banking.

Creal, D., Schwaab, B., Koopman, S. J., Lucas, A., 2014. Observation-driven mixed-measurement dynamic factor models with an application to credit risk. Review of Economics and Statistics $96(5), 898-915$.

Croissant, Y., Millo, G., et al., 2008. Panel data econometrics in r: The plm package. Journal of Statistical Software 27 (2), 1-43.

D'Avino, C., 2018. Quantitative easing, global banks and the international bank lending channel. Economic Modelling.

Eaton, J., Gersovitz, M., Stiglitz, J. E., 1991. The pure theory of country risk. In: International Volatility and Economic Growth: The First Ten Years of The International Seminar on Macroeconomics. Elsevier Science Publishers BV, pp. 391-435.

Elton, E. J., Gruber, M. J., 1997. Modern portfolio theory, 1950 to date. Journal of Banking \& Finance 21 (11-12), 1743-1759. 
Gregory, J., 2010. Counterparty credit risk: the new challenge for global financial markets. Vol. 470. John Wiley \& Sons.

Grilli, R., Tedeschi, G., Gallegati, M., 2014. Bank interlinkages and macroeconomic stability. International Review of Economics \& Finance 34, 72-88.

Grossman, H. I., Van Huyck, J. B., 1988. Sovereign debt as a contingent claim: Excusable default, repudiation, and reputation. The American Economic Review 78 (5), 1088-1097.

Herrero, A. G., Peria, M. S. M., 2007. The mix of international banks foreign claims: determinants and implications. Journal of banking \& Finance 31 (6), 1613-1631.

Herrmann, S., Mihaljek, D., 2013. The determinants of cross-border bank flows to emerging markets. Economics of transition 21 (3), 479-508.

Hills, R., Reinhardt, D., Sowerbutts, R., Wieladek, T., et al., 2017. International banking and cross-border effects of regulation: Lessons from the united kingdom. International Journal of Central Banking 13 (2), 404-433.

Houpt, J. V., 1999. International activites of us banks and in us banking markets. Fed. Res. Bull. 85,599 .

Imbierowicz, B., Rauch, C., 2014. The relationship between liquidity risk and credit risk in banks. Journal of Banking \& Finance 40, 242-256.

Jang, K. Y., 2017. The effect of tarp on the propagation of real estate shocks: Evidence from geographically diversified banks. Journal of Banking \& Finance 83, 173-192.

Kharroubi, E., Kohlscheen, E., 2017. Statistical data. BIS Quarterly Review (6). 
Klein, R. W., Bawa, V. S., 1976. The effect of estimation risk on optimal portfolio choice. Journal of Financial Economics 3 (3), 215-231.

Koopman, S. J., Lucas, A., Schwaab, B., 2012. Dynamic factor models with macro, frailty, and industry effects for us default counts: the credit crisis of 2008. Journal of Business \& Economic Statistics 30 (4), 521-532.

Lee, E.-J., 2017. Intra-and inter-regional portfolio diversification strategies under regional market integration: Evidence from us global banks. International Review of Financial Analysis 54, 1-22.

Liu, E. X., Pogach, J., 2017. The effect of foreign lending on domestic loans: An analysis of us global banks. Economics Letters 156, 151-154.

Mckinnon, R. I., 2010. Money and capital in economic development. Brookings Institution Press.

Niepmann, F., Schmidt-Eisenlohr, T., 2017. No guarantees, no trade: How banks affect export patterns. Journal of International Economics 108, 338-350.

Palmer, D. E., 2000. Us bank exposure to emerging-market countries during recent financial crises. Fed. Res. Bull. 86, 81.

R Core Team, 2017. R: A Language and Environment for Statistical Computing. R Foundation for Statistical Computing, Vienna, Austria.

URL https://www.R-project.org/

Rose, A. K., Spiegel, M. M., 2010. Cross-country causes and consequences of the 2008 crisis: International linkages and american exposure. Pacific Economic Review 15 (3), 340-363.

Rose, A. K., Spiegel, M. M., 2011. Cross-country causes and consequences of the crisis: An update. European Economic Review 55 (3), 309-324. 
Sedunov, J., 2016. What is the systemic risk exposure of financial institutions? Journal of Financial Stability $24,71-87$.

Theil, H., 1965. Optimal decision rules for government and industry,. In: Revue Economique 16 (6), p. 982 .

\section{Appendix}
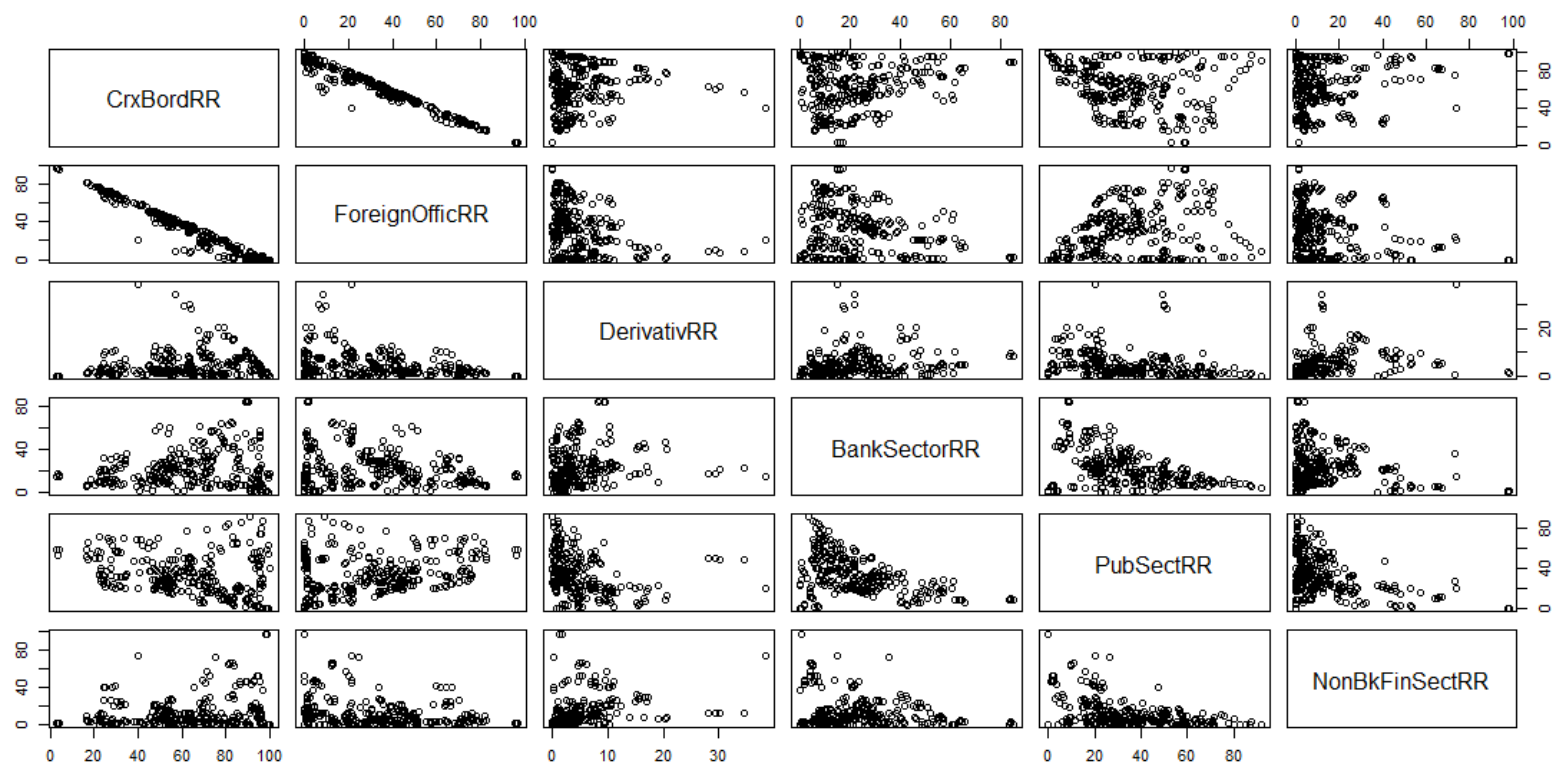

NonBkFinSectRR

Figure 1: Pair-wise graphical correlation test for all variables in the analysis 


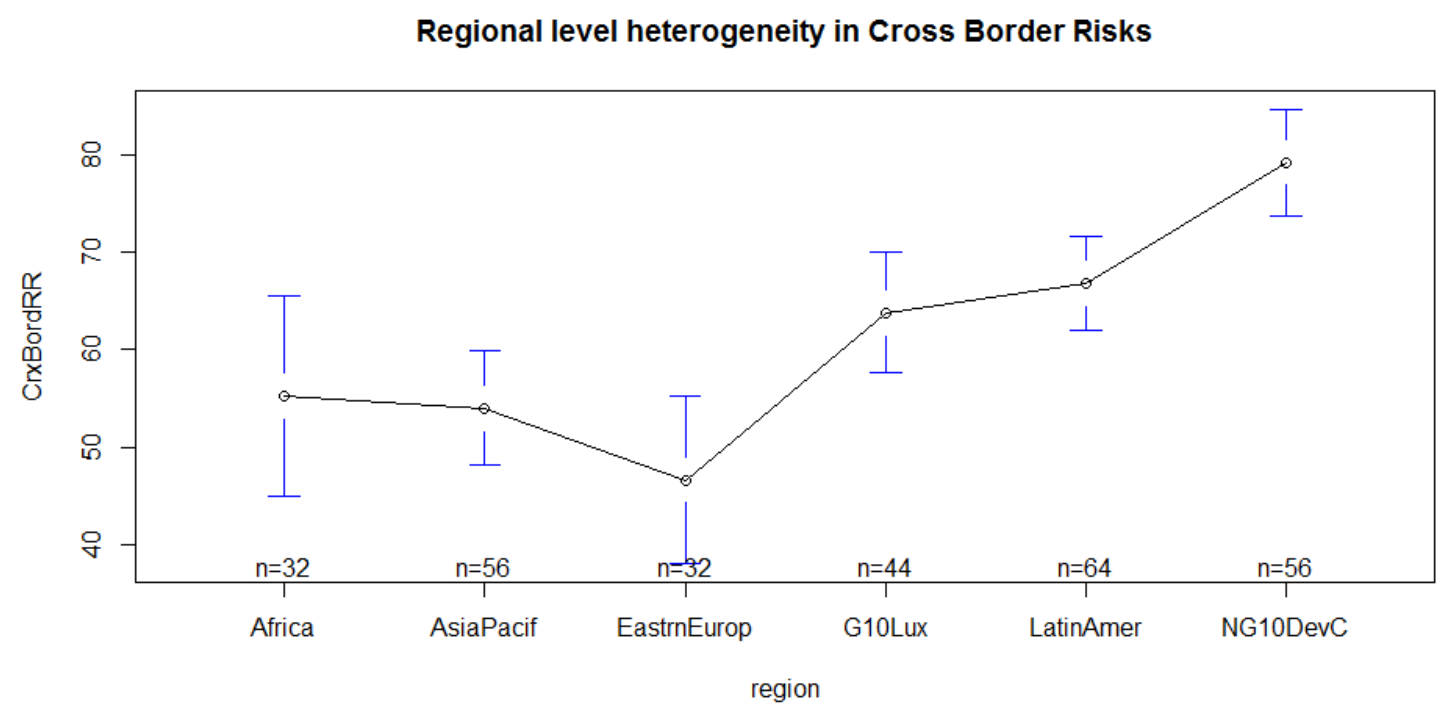

Figure 2: Aggregate regional heterogeneity in U.S. global banks' cross-border risk exposure

Regional level heterogeneity in Foreign Office Risks

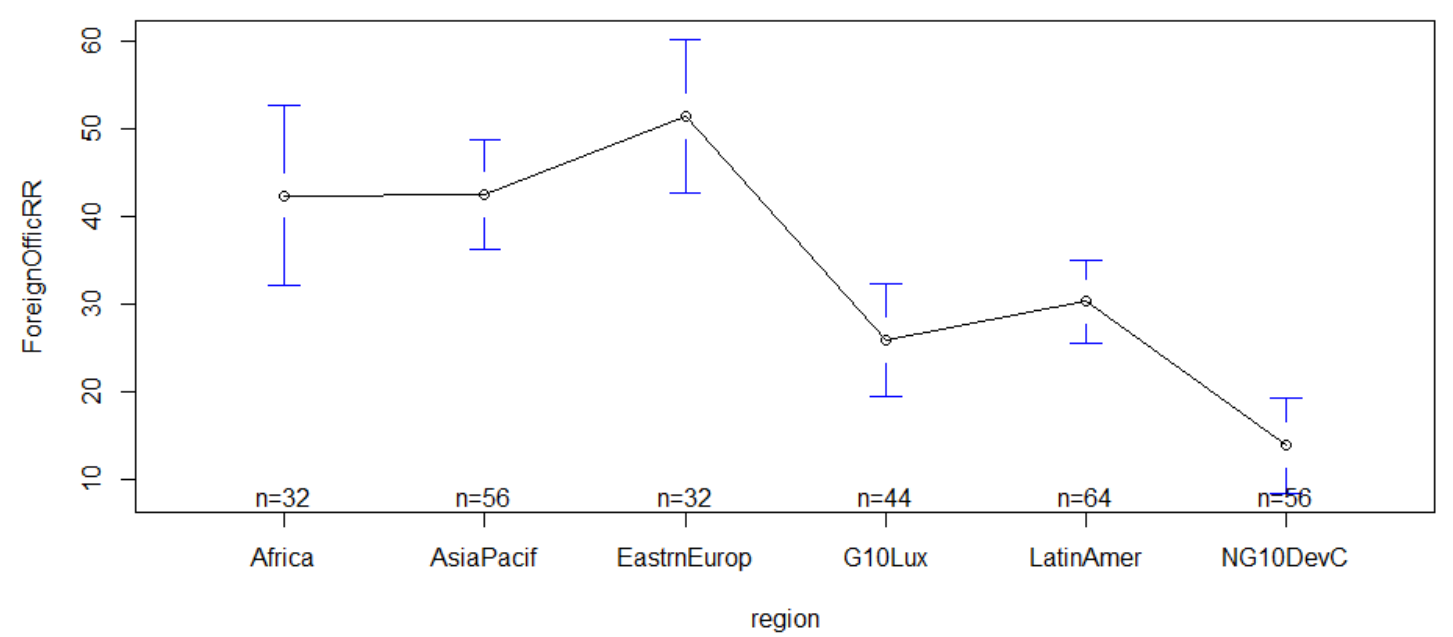

Figure 3: Aggregate regional heterogeneity in U.S. global banks' foreign office risk exposure 


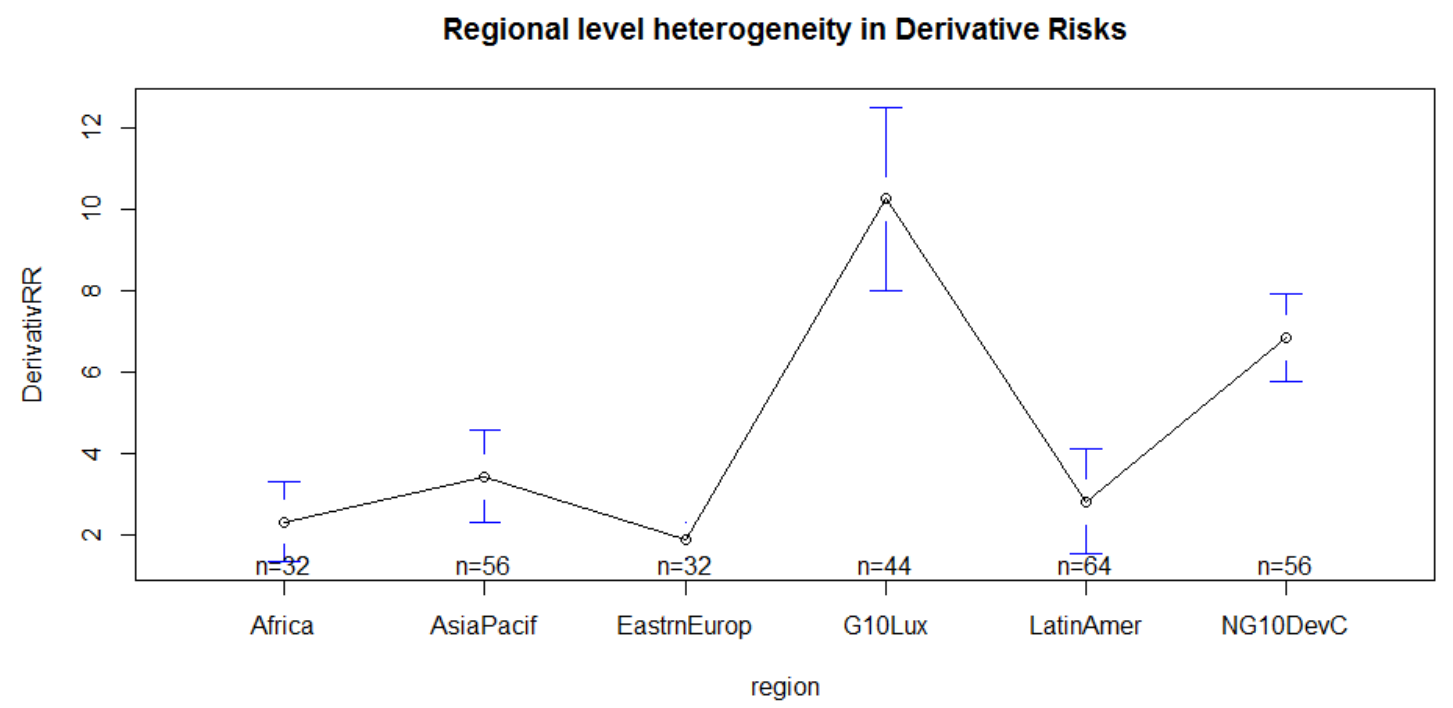

Figure 4: Aggregate regional heterogeneity in U.S. global banks' derivative risk exposure

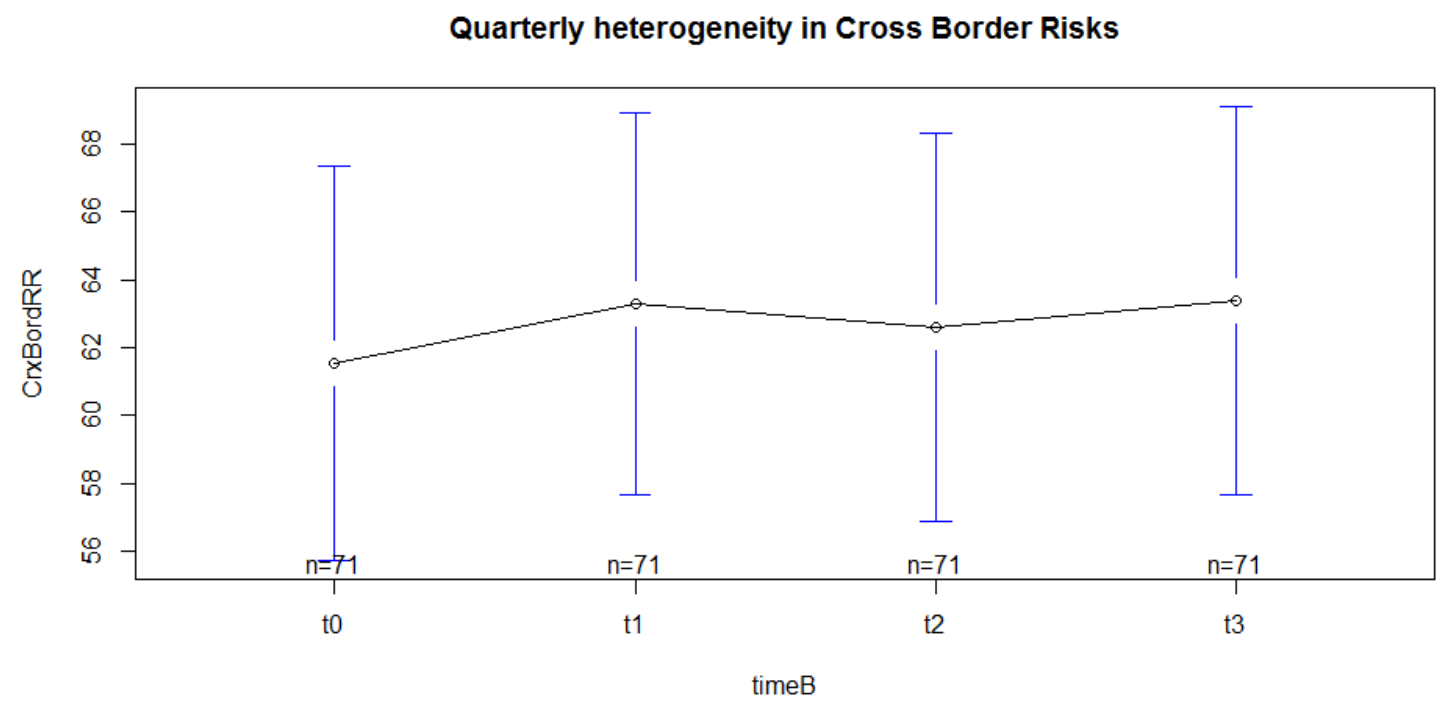

Figure 5: Aggregate quarterly heterogeneity in U.S. global banks' cross-border risk exposure 


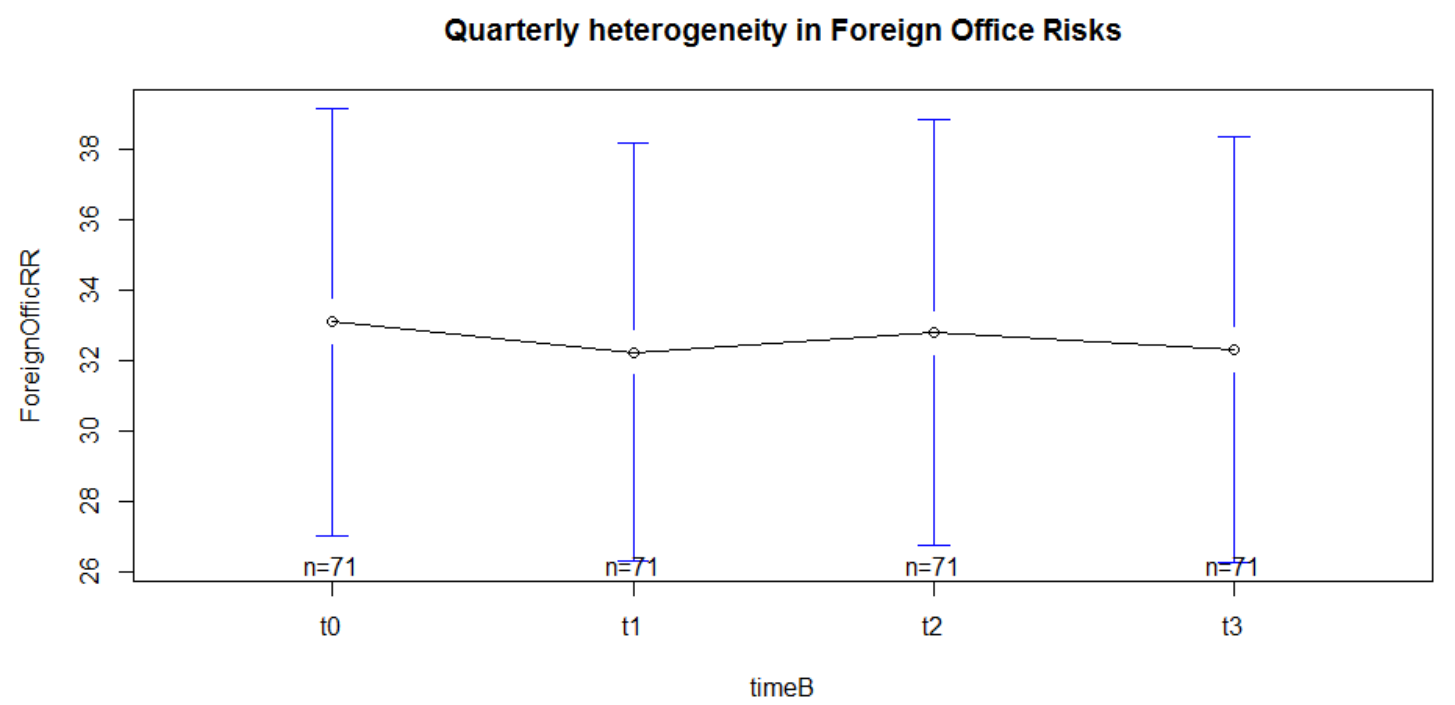

Figure 6: Aggregate quarterly heterogeneity in U.S. global banks' foreign office risk exposure

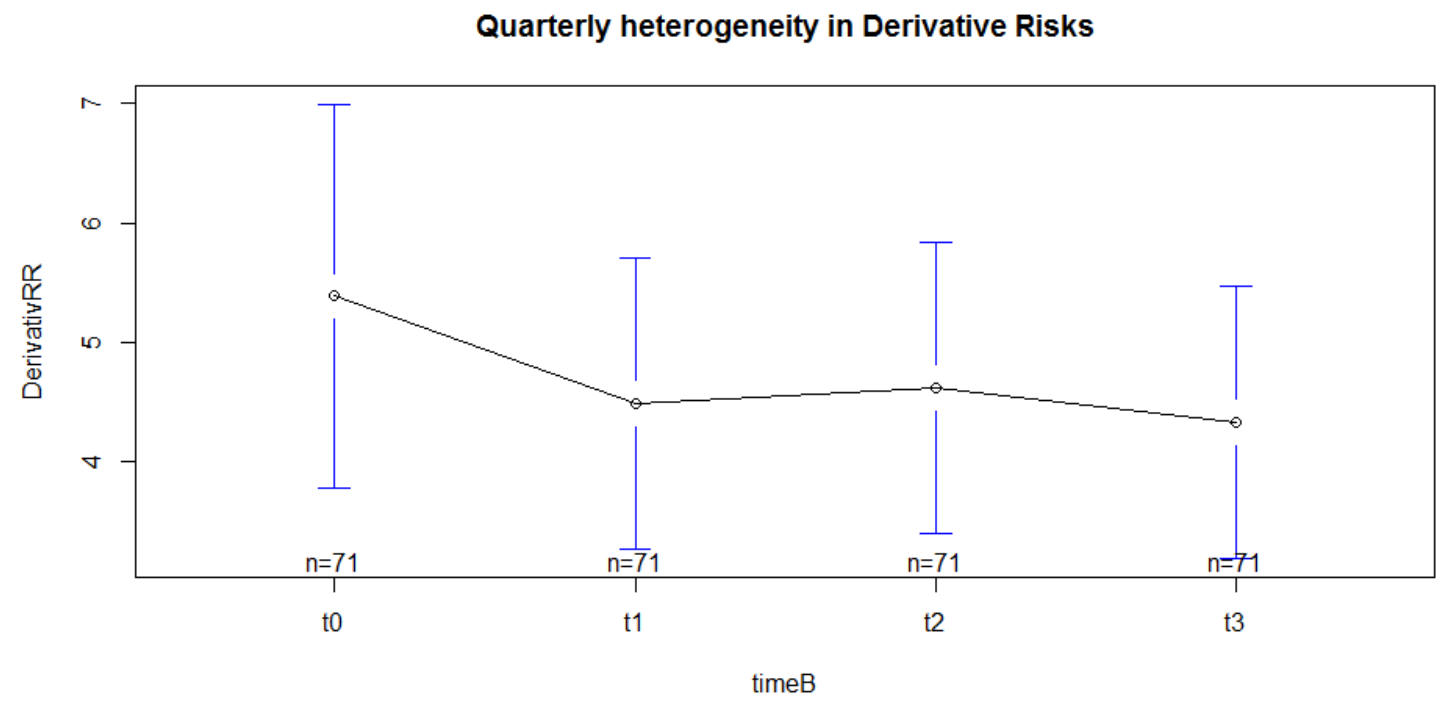

Figure 7: Aggregate quarterly heterogeneity in U.S. global banks' derivative risk exposure 
Table 1: Descriptive Statistics (mean and standard deviation) of the variables

\begin{tabular}{lcccc|c}
\hline Variables (\%) & Q4- 2016 & Q1- 2017 & Q2- 2017 & Q3- 2017 & Total \\
\hline CrxBordRR & 61.53 & 63.28 & 62.61 & 63.38 & 62.70 \\
ForeignOfficRR & $(24.51)$ & $(23.72)$ & $(24.16)$ & $(24.20)$ & $(24.03)$ \\
& 33.08 & 32.23 & 32.77 & 32.29 & 32.59 \\
DerivativRR & $25.6)$ & $(25.05)$ & $(25.51)$ & $(25.49)$ & $(25.29)$ \\
& 5.39 & 4.49 & 4.62 & 4.33 & 4.71 \\
PubSectRR & $(6.77)$ & $(5.15)$ & $(5.13)$ & $(4.80)$ & $(5.50)$ \\
& 23.01 & 22.47 & 21.96 & 21.56 & 22.25 \\
BankSectorRR & $(17.78)$ & $(16.87)$ & $(16.85)$ & $(16.72)$ & $(16.98)$ \\
& 33.16 & 33.81 & 34.88 & 34.89 & 34.18 \\
NonBkFinSectRR & 13.88 & 12.75 & 13.03 & 13.27 & 13.23 \\
& $(17.49)$ & $(16.80)$ & $(17.21)$ & $(17.47)$ & $(17.16)$ \\
\hline
\end{tabular}

Source: Author's construction using the Data 
Table 2: Pearson Correlation Coefficients with corresponding 95\% Confidence Interval

\begin{tabular}{|c|c|c|c|c|c|c|}
\hline & CrxBordRR & ForeignOfficRR & DerivativRR & PbSctRR & BkSctRR & NBkFinSctRR \\
\hline \multirow[t]{2}{*}{ CrxBordRR } & 1.00 & $-0.98^{*}$ & $0.12^{* * *}$ & $-0.23^{*}$ & $0.19^{* *}$ & $0.23^{* * *}$ \\
\hline & & $(-0.98,-0.97)$ & $(-0.43,-0.22$ & $2)-0.34,-0$. & $12)(0.08,0.30)$ & $(0.11,0.34)$ \\
\hline \multirow[t]{2}{*}{ ForeignOfficRR } & & 1.00 & $-0.33^{*}$ & $0.28^{* * *}$ & $-0.22^{* * *}$ & $-0.28^{* * *}$ \\
\hline & & & $(-0.43,-0.22$ & 2) $(0.17,0.38$ & $8)(-0.33,-0.10$ & $0)(-0.38,-0.17)$ \\
\hline \multirow[t]{2}{*}{ DerivativRR } & & & 1.00 & $-0.27^{* * *}$ & $0.17^{* *}$ & $0.28^{* * *}$ \\
\hline & & & & $(-0.38,-0$. & $16)(0.06,0.28)$ & $(0.17,0.38)$ \\
\hline \multirow[t]{2}{*}{ PubSectRR } & & & & 1.00 & $-0.45^{* * *}$ & $-0.47^{* * *}$ \\
\hline & & & & & \multicolumn{2}{|c|}{$(-0.54,-0.35)(-0.55,-0.37)$} \\
\hline \multirow[t]{2}{*}{ BankSectorRR } & & & & & 1.00 & $-0.18^{* *}$ \\
\hline & & & & & & $(-0.29,-0.07)$ \\
\hline NonBkFinSectRR & & & & & & 1.00 \\
\hline
\end{tabular}

${ }^{* * *} p<0.001,{ }^{* *} p<0.01,{ }^{*} p<0.05,\left(L_{b}, U_{b}\right)$ is the $95 \%$ CI

Source: Author's construction using the Data 
Table 3: Pooled OLS and Panel Fixed Effects Models Results for Cross border risk (CrxBordRR)

\begin{tabular}{|c|c|c|}
\hline & Pooled OLS & Panel Fixed Eff. \\
\hline \multirow[t]{2}{*}{ (Intercept) } & $47.30^{* * *}$ & \\
\hline & $(6.70)$ & \\
\hline \multirow[t]{2}{*}{ BankSectorRR } & $0.35^{* * *}$ & $0.34^{* *}$ \\
\hline & $(0.10)$ & $(0.12)$ \\
\hline \multirow[t]{2}{*}{ PubSectRR } & 0.02 & $0.21^{*}$ \\
\hline & $(0.10)$ & $(0.09)$ \\
\hline \multirow[t]{2}{*}{ NonBkFinSectRR } & $0.39^{* * *}$ & 0.02 \\
\hline & $(0.10)$ & $(0.03)$ \\
\hline \multirow[t]{2}{*}{ (Quarter)t1/t0 } & 2.38 & $1.83^{*}$ \\
\hline & $(3.85)$ & $(0.78)$ \\
\hline \multirow[t]{2}{*}{ (Quarter)t2/t0 } & 1.76 & 1.09 \\
\hline & $(3.85)$ & $(0.79)$ \\
\hline \multirow[t]{2}{*}{ (Quarter)t3/t0 } & 2.58 & $2.00^{*}$ \\
\hline & $(3.85)$ & $(0.79)$ \\
\hline F-statistics & 5.69 & 2.64 \\
\hline P-value & $1.34 e-05$ & 0.02 \\
\hline Num. obs. & 284 & 284 \\
\hline Poolability test results & \multicolumn{2}{|c|}{ Fixed Effect } \\
\hline $\mathrm{F}=93.288$, and $\mathrm{p}<0.05$ & \multicolumn{2}{|c|}{ Model better } \\
\hline
\end{tabular}


Table 4: Pooled OLS and Panel Fixed Effects Models Results for Foreign Office risk (ForeignOfficRR)

\begin{tabular}{|c|c|c|}
\hline & Pooled OLS & Panel Fixed Eff. \\
\hline \multirow[t]{2}{*}{ (Intercept) } & $49.75^{* * *}$ & \\
\hline & $(6.88)$ & \\
\hline \multirow[t]{2}{*}{ BankSectorRR } & $-0.42^{* * *}$ & -0.13 \\
\hline & $(0.11)$ & $(0.12)$ \\
\hline \multirow[t]{2}{*}{ PubSectRR } & -0.01 & -0.02 \\
\hline & $(0.10)$ & $(0.08)$ \\
\hline \multirow[t]{2}{*}{ NonBkFinSectRR } & $-0.49^{* * *}$ & $-0.09^{* *}$ \\
\hline & $(0.11)$ & $(0.03)$ \\
\hline \multirow[t]{2}{*}{ (Quarter)t1/t0 } & -1.63 & -1.01 \\
\hline & $(3.95)$ & $(0.76)$ \\
\hline \multirow[t]{2}{*}{ (Quarter)t2/t0 } & -1.17 & -0.48 \\
\hline & $(3.95)$ & $(0.77)$ \\
\hline \multirow[t]{2}{*}{ (Quarter)t3/t0 } & -1.70 & -0.99 \\
\hline & $(3.95)$ & $(0.77)$ \\
\hline F-statistics & 8.30 & 1.63 \\
\hline P-value & $2.79 e-08$ & 0.14 \\
\hline Num. obs. & 284 & 284 \\
\hline Poolability test results & \multicolumn{2}{|c|}{ Fixed Effect } \\
\hline $\mathrm{F}=104.74$, and $\mathrm{p}<0.05$ & \multicolumn{2}{|c|}{ Model better } \\
\hline
\end{tabular}


Table 5: Pooled OLS and Panel Fixed Effects Models Results for Derivatives risk (DerivativRR)

\begin{tabular}{|c|c|c|}
\hline & Pooled OLS & Panel Fixed Eff. \\
\hline \multirow[t]{2}{*}{ (Intercept) } & 2.95 & \\
\hline & $(1.52)$ & \\
\hline \multirow[t]{2}{*}{ BankSectorRR } & $0.07^{* *}$ & $-0.22^{* * *}$ \\
\hline & $(0.02)$ & $(0.05)$ \\
\hline \multirow[t]{2}{*}{ PubSectRR } & -0.01 & $-0.19^{* * *}$ \\
\hline & $(0.02)$ & $(0.04)$ \\
\hline \multirow[t]{2}{*}{ NonBkFinSectRR } & $0.09^{* * *}$ & $0.06^{* * *}$ \\
\hline & $(0.02)$ & $(0.01)$ \\
\hline \multirow[t]{2}{*}{ (Quarter)t1/t0 } & -0.75 & $-0.82^{*}$ \\
\hline & $(0.87)$ & $(0.34)$ \\
\hline \multirow[t]{2}{*}{ (Quarter)t2/t0 } & -0.59 & -0.61 \\
\hline & $(0.87)$ & $(0.34)$ \\
\hline \multirow[t]{2}{*}{ (Quarter)t3/t0 } & -0.88 & $-1.00^{* *}$ \\
\hline & $(0.87)$ & $(0.34)$ \\
\hline F-statistics & 7.04 & 12.17 \\
\hline P-value & $5.44 e-07$ & $1.04 e-11$ \\
\hline Num. obs. & 284 & 284 \\
\hline Poolability test results & \multicolumn{2}{|c|}{ Fixed Effect } \\
\hline $\mathrm{F}=23.72$, and $\mathrm{p}<0.05$ & \multicolumn{2}{|c|}{ Model better } \\
\hline
\end{tabular}

